\title{
COVID-19 outbreak and Urban dynamics: regional variations in India
}

\author{
Devarupa Gupta $\mathbb{D} \cdot$ Dibyendu Biswas $\cdot$ Pintu Kabiraj
}

Accepted: 9 February 2021 / Published online: 3 March 2021

(C) The Author(s), under exclusive licence to Springer Nature B.V. part of Springer Nature 2021

\begin{abstract}
India was the second highest COVID-19 affected country in the world with 2.1 million cases by 11th August. This study focused on the spatial transmission of the pandemic among the 640 districts in India over time, and aimed to understand the urbancentric nature of the infection. The connectivity context was emphasized that possibly had inflicted the outbreak. Using the modes of transmission data for the available cases, the diffusion of this disease was explained. Metropolitans contributed three-fourths of total cases from the beginning. The transport networks attributed significantly in transmitting the virus from the urban containment zones. Later, there was a gradual shift of infections from urban to rural areas; however, the numbers kept increasing in the former. The massive reverse migration after lockdown spiked
\end{abstract}

D. Gupta $(\bowtie)$

International Institute for Population Sciences, Govandi

Station Road, Deonar, Mumbai 400088,

Maharashtra, India

e-mail: devarupagupta140890@gmail.com

D. Gupta

Purulia, India

D. Biswas · P. Kabiraj

Institute of Development Studies Kolkata, 27/D, DD

Block, Sector 1, Salt Lake, Kolkata 700064,

West Bengal, India

e-mail: dibyendubiswas92@gmail.com

P. Kabiraj

e-mail: pintukabirajs@gmail.com the infected cases further. Districts with airports reported more with influx of international passengers. A profound east-west division in April with higher infections in the southern and western districts existed. By mid-May eastern India saw a steep rise in active cases. Moran's I analysis showed a low autocorrelation initially which increased over time. Hotspot clustering was observed in western Maharashtra, eastern Tamil Nadu, Gujarat and around Kolkata by the second week of August. The diffusion was due to travel, exposure to infected individuals and among the frontline workers. Spatial regression models confirmed that urbanization was positively correlated with higher incidences of infections. Transit mediums, especially rail and aviation were positively associated. These models validated the crucial role of spatial proximity in diffusion of the pandemic.

Keywords COVID-19 · Urban-centric · Cities · Modes of transmission - Travel networks - Spatial regression models

\section{Introduction}

The rapid urban growth occurring since the later half of the twentieth century led to an estimated 55.3 percent of the world's population living in urban settlements and is expected to hit the 60 percent mark 
by 2030 (United Nations 2019). This upsurge in urban population was much rapidly contributed by the continents of Africa and Asia than other regions of the world. In Asia, India is the highest populated country, falling only behind China. Presently, about 377.1 million people in India are urban dwellers, tallying to 31.6 percent of the country's total population (Census of India 2011). The rapid influx of urban residents burdened the cities with increased built-up areas, pushing people to previously untouched ecosystems (Neiderud 2015). Unplanned urbanization led to environmental changes by anthropogenic factors and intimidated human health by creating food and water scarcity, natural disasters, displaced populations, and the epidemiology of infectious diseases (Myers and Patz 2009). Diseases re-structured urban expansions over centuries, redistributing population over space. A swift increase in the urban population in the lower latitudes imposed newer risks from microbes and antibiotic resistant new diseases (Mack et al. 2010). The rise in the number of new cities especially in the developing world, led to hyperdense settlements, creating potential risks and vulnerabilities in the aspect of emerging infectious diseases and the close contact among people generated hotspots for their rapid spread (Neiderud 2015). Encroachment into natural habitats and closer proximity to wild animals might be the root cause for diseases like SARS and COVID-19 (Lee et al. 2020). Intensified and unscientific animal keeping methods raised the import of earlier unknown pathogens, increasing the exposure to newer hosts (Lindahl and Grace 2015). Studies concluded that urbanization increased agriculture, changed socioeconomic behaviour and fragmented the ecological balance, which have profoundly impacted on the ecology of infectious diseases (Hassell et al. 2017; Vignier and Bouchaud 2018). Improvements in connectivity posed catalyst for outbreaks like Chagas disease in Latin America, Seoul Hantavirus, SARS, MERS, AIDS and Ebola. Traditional rural infectious diseases like lymphatic Filariasis, Dengue, Leishmaniasis, West Nile Virus (WNV) infection, etc. adapted to the urban environment (Neiderud 2015). Redefining the public health interventions and new approaches that consider urban determinants of health are necessary to meet the challenges faced by the urban poor as a result of rapid population growth and unplanned urbanization (Katz et al. 2012).
The emergence of COVID-19 caused by the novel coronavirus, SARS-CoV-2 in the Wuhan city of Hubei, China in early December 2019, took a form of the global pandemic within a very short span. Declared by the World Health Organization (WHO), as an international public health emergency, it affected over 213 countries and over 26 million people globally (5 September 2020). The first case in India was reported on 30 January 2020, a student who returned from Wuhan to Thrissur, Kerala. The first fatality in the country was in Karnataka on 11 March with a travel history from Saudi Arabia. As a preventive measure, the Indian government imposed a nationwide lockdown 24 March 2020, preceeded by the 'Janta Curfew' on 22nd March and further restricted international airflow and within country movements for the next few months. By 11 August about 21 million cases were reported in India. Numerous studies tried to understand the transmission dynamics of COVID-19 by using Reproduction Infection Rates $\left(\mathrm{R}_{0}\right.$ and $\mathrm{R}_{1}$ ) to gauge how likely the outbreak will spread in India (Khajanchi and Sarkar 2020; Rafiq et al. 2020; Patil et al. 2020; Arora et al. 2020). The data driven models measured how contagious a disease was by using Basic Reproduction Rate $\left(\mathrm{R}_{0}\right)$. The conditions were; for $\mathrm{R}_{0}<1$, the disease would stop spreading, for $\mathrm{R}_{0}=1$, an infected person could infect a single person on an average and if $R_{0}>1$, the disease could become an epidemic (Khajanchi et al. 2020a, b). The local and global asymptotic stability analysis stated that the disease turned out to be an epidemic within a very short time and predicted that by the intervention methods of practicing social distancing, lockdown effect and use of precautionary measures like isolation, quarantine and hospitalization (Biswas et al. 2020; Samui et al. 2020) the transmission of the disease could be curbed. Sarkar et al. (2020) concluded that the number of infected individuals might increase in India if human-to-human transmission and personal preventive measures were not applied, considering the existing rates of the testing which were lower than the required.

\section{Travel networks and pandemics}

With globalization, diseases cross geopolitical borders with human movements, termed explicitly as 'mobility'. Historical determinants associated with human 
mobility such as movements and behaviors, trade and commerce, host susceptibility factors, and social inequality affected infectious disease occurrence (Morens et al. 2004). Over administrative borders, regions differ in disease epidemiology, general health disparities and factors like poverty, education, housing, and nutrition and care (Mack et al. 2010). Epidemics like the plague in Athens (430-426 BC), Black Death in medieval Europe (1347-1350), Spanish flu (1918-1920) and AIDS pandemic across the African continent and then the world (from 1981 onwards) were transmitted along the trade routes (Morens et al. 2008). The influx of traders, businessmen, travelers, pilgrims, colonists, and soldiers etc. for centuries impacted on the spread of infections (Cartwright 1972; Curtin 1989). Archives mention isolation of ill travelers as initial public health interventions before detection of the disease (Gushulak and MacPherson 2000). Most notably, the growing commercial aviation industry, international travel, and commerce aided to the rapid distribution of the pathogens of many deadly epidemics in the globalized world (IOM 2003). SARS (2002), drug-resistant malaria endemic in 92 countries (Martens and Hall 2000), Chikungunya in Italy (Rezza et al. 2007), and Swine Flu influenza (H1N1) (2009) were some of the recent global endemics. Ryan et al. (2002) carried out a selective review of a few specific illnesses often diagnosed in travellers from the developing regions. They estimated that between 20 and 70 percent of the travellers reported some symptoms of tropical illnesses associated with their travel each year (ibid). A study by Hufnagel et al. (2004) carried out simulations between local infection dynamics and individuals' traveling behavior by global aviation networks showed that by isolating $2 \%$ of the largest cities, the outbreak of an epidemic could be drastically reduced. A mathematical modelling by Kucharski et al. (2020) on transmission of COVID-19 found that $\mathrm{R}_{t}$ ranging between 1.6 and 2.6 in Wuhan in January, almost declined to half in two weeks with the introduction of travel restrictions in the city. Using data of airport screenings of incoming passengers from abroad, a study in India (Mandal et al. 2020) predicted that there remained a high probability that every affected person can transmit the virus to 1.5 to 4 individuals. The study also found out that the high-density cities of the country were worst affected.

\section{Transmission of infections in urban settings}

City life is closely associated with mobility, intermixing, and risk-taking behavior, which eventually makes it vulnerable to transmissions compared to their rural counterparts, especially in developing countries (Saker et al. 2004). A rapid in-migration results in more slums or housing shortages, leading to zoonotic outbreaks (Jones et al. 2008; Lee et al. 2020). McMichael and McMichael (1993) used the term 'crowd infections' to denote the outbreak of bacteria and viruses among a densely non-immune population in the urban settings. The consequences of 'imported' and 'exported' infected cases are massive in the travel industry and in a country's medical sector (ibid). SARS outbreak (2003) was transmitted to Hong Kong by a physician traveling from Guangdong, China, unchecked for symptoms due to an absence of border health controls (Abdullah et al. 2004). After the infection spread to his fellow lodgers, they carried the disease to their respective countries, thus starting the global SARS epidemic (ibid). The rapid spread of COVID-19 showed the potential threat that an infectious disease poses in a closely-knit world in the twenty-first century. Dr. Michael Ryan, Executive Director, WHO Health Emergencies program, addressed the incidence of higher outbreaks in urban centres with improved travel networks of Europe and North America, compared to Africa at a virtual press conference (13 April 2020). He described the disease penetration from urban-centric core to the periphery with the movement of people, the distance, and social contact between individuals and the environment. Further, there remained a possibility of weaker surveillance in rural areas, that might have underdetected its prevalence. An article published early March (2020) in Forbes (Nace 2020) reported rapid rise of community-level infections in all the larger metropolitan areas in the top ten globally most COVID-19 affected countries; China, UK, USA, South Korea, France, Germany, Iran, Spain, Switzerland, and Italy. The pandemic in India seemed a complex aggregation of several individual outbreaks that occurred at different time points in different geographic locations in the country, mainly because of the varying population density, influenced by mobility patterns and the available healthcare system, which greatly affected the varying trajectories across the states in response of the effect of the nationwide 
lockdown (Mitra et al. 2020). Common disruptive factors for the spread of pandemics in urban areas included higher population density, commutation through public transport, and high indoor-work-environments (Lee et al. 2020). Higher occupant density in built-up environments and increased indoor activity raised the human-to-human contact (Andrews et al. 2014). Effect of media awareness had a good impact in mitigating disease transmission at the initial stage (Khajanchi et al. 2020a, b) and they suggested that isolation or hospitalization of the patients, hygiene safeguards and social distancing practices can effectively control the transmission and ultimately eliminate the disease.

\section{Rationale of the study}

An epidemic is a biological occurrence, but its transmission is driven by many socio-cultural factors, among which urbanization plays a crucial role. On one hand, it favours overall development, yet on the other, overcrowding in cities and human mobility networks provides a perfect setup for the spread of infections. This study focused on the spatial transmission dynamics of COVID-19 and its outbreak pattern in India at the district level over time. Multiple studies took a predictive and curable approach to address the pandemic. Here, we tried to understand the dynamics of transmission, which went unremarked in many discussions. We focused on the issue of the urbancentric nature of the pandemic. We emphasized on the connectivity context that possibly inflicted the transmission by considering the travel routes and relating with the disease spread. Using data on the mode of transmission, we explained the diffusion pattern of the virus among the population. Our study addressed questions like: What is the spatial pattern of COVID19 transmission in India? Is the disease urbancentric? What are the chief modes of transmission of the disease?

\section{Data and methods}

In India, district-wise COVID-19 infection information was not coherently provided by any government agency; thus, we relied on two non-government data sources https://www.howindialives.com and https:// www.covid19india.org/. The total number of infected cases were collected from the first source from 22 March to 11 August 2020. These websites collected data from different state government bulletins, the Indian Council of Medical Research (ICMR) bulletins, and the Ministry of Health and Family Welfare (MoHFW) publications and other sources. The study considered districts as the spatial units of analysis. In 2020, there are more than 700 districts in India compared to 640 mentioned in the Census of 2011, so by making necessary adjustments we equalized the numbers as in 2011. An important issue in infectious disease epidemiology is to identify and predict geographic sites of epidemic establishment from where the disease spreads (Kissler et al. 2019) generally located in densely-populated, well-connected areas. Relating to this, we accessed the urbanization rates from the Census of India data. The month-wise international and domestic air passenger data by Airport Authority of India across 126 airports were availed from January to March 2020. Access to any real-time data on surface passenger flow (rail and road) was unavailable; thus, the road and rail density at district level was considered a proxy of surface mobility. We accessed this data from https://www. diva-gis.org/. For the temporal analysis, a fifteen days' time interval was maintained initially. We considered the incubation period of two weeks of the disease and tried to show the spatial spread from 22 March to 3 June. We considered the days of the three unlock periods that followed (3rd June, 1st July and 1st August), to understand the post-lockdown situation and ultimately completed the time frame till 11th August 2020.

We strategized the study with initially explaining the district-wise distribution of reported COVID-19 cases in the country through dot density maps superimposed on thematic maps representing percent urban population in districts. We used LISA spatial autocorrelation technique next to generate cluster maps to understand if the observations at spatial locations were similar or dissimilar to their neighbours. Measures of global clustering, are powerful tools for analysis of spatially resolved data on infectious diseases (Lessler et al. 2016). Calculations were conducted for 22 March, 21 April, 19 May, 3 June, 1st July and 11 August 2020 at a 95 percent confidence interval. Five scenarios distinguishing COVID-19 clusters in the country were observed with 
high-high (Hotspots), low-low (Coldspots), low-high (Spatial Outliers), high-low (Spatial Outliers), and no significant local autocorrelation values.

To understand the spread of COVID-19, we classified the states and districts into higher urbanized and lower urbanized based on their level of urbanization and the national urbanization rate (31\% in 2011). models indicated the presence of spatial dependence in the data (Table 1). In general, there are two types of spatial dependence; first, the spatial error dependence which designates that the error terms across different spatial units are correlated (Anselin et al. 2006). Second, the spatial lag dependence, which specifies that the dependent variable in a particular region is

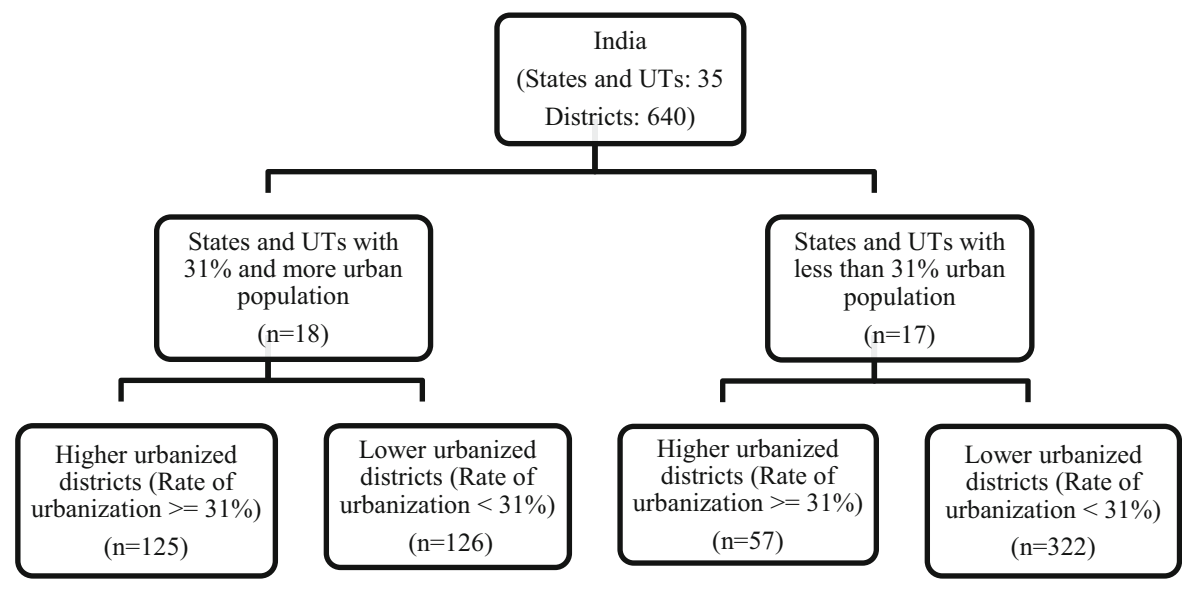

The dynamics of the pandemic spread was explained with the analysis of the medium of transmissions of COVID-19 till the first week of May. Information was collected from https://www. covid19india.org/ which collected information from the Centre and State publications, news bulletins and reports, social media platforms like Twitter, etc. We categorized them into six categories: namely travel (international and domestic), accidental exposure to a COVID-19 patient, family members of patients, frontline workers, and other reasons. Information was available for roughly one-tenth of the total cases until May; after which with the increase in the number of infections, the details lessened. We compiled information on modes of transmission of COVID-19 between 22 March and 5 May 2020.

Last, we constructed three separate sets of OLS models and their spatial lag variants to understand the effects of urbanization and transit mediums on the spread of this pandemic. Multiple studies used the spatial lag model to understand the spatial patterns of infectious disease (Zhang et al. 2019; Lessler et al. 2016; O'Brien and Xagoraraki 2019). The significant and positive test scores of Moran's I, Lagrange Multiplier Lag, Lagrange Multiplier Error, and Spatially Autoregressive Moving Average for all three affected by the independent variables in both that specific place and its neighbouring area. Here, the dependent variable was the COVID cases (11 August) and the independent variables were: hand washing with soap, having an internet connection, percentage of the urban population, rail per hundred sq. Km., road per hundred sq. Km., secondary level of education and above and hospital beds per hundred thousand population (Table 2). After identifying the presence of spatial dependence, we re-estimated the OLS models with the maximum likelihood approach while controlling for spatial lag dependence. We considered spatial lag models instead of spatial error assuming that dependency existed directly among the levels of the dependent variable (district wise COVID-19

Table 1 Diagnostic for spatial dependence

\begin{tabular}{llrl}
\hline Test & MI/DF & Value & Probability \\
\hline Moran's I (error) & 0.22 & 9.51 & 0 \\
Lagrange Multiplier (lag) & 1 & 76.51 & 0 \\
Lagrange Multiplier (error) & 1 & 83.77 & 0 \\
Lagrange Multiplier (SARMA) & 2 & 84.21 & 0 \\
\hline
\end{tabular}

Unlock 3 extended to 31 August. Later 4 more unlock phases were announced 
Table 2 Rationale behind selecting the independent variables in the models

\begin{tabular}{|c|c|c|}
\hline Variables used & Rationale & Source \\
\hline Proportion of urban population & Development indicator, high population density & $\begin{array}{l}\text { Census of India } \\
\text { (2011) }\end{array}$ \\
\hline Rail lines per hundred sq. km & $\begin{array}{l}\text { Major transport routes for intra and interstate movements, return } \\
\text { migration, unlocking of services with Shramik Special Trains }\end{array}$ & $\begin{array}{l}\text { https://www.diva- } \\
\text { gis.org/ }\end{array}$ \\
\hline Roads per hundred sq. km & Major surface transit routes for movement & $\begin{array}{l}\text { https://www.diva- } \\
\text { gis.org/ }\end{array}$ \\
\hline Airport availability & Air travel routes, international and domestic passenger transfer & $\begin{array}{l}\text { Airport Authority } \\
\text { of India (2020) }\end{array}$ \\
\hline $\begin{array}{l}\text { Handwashed with soap (percentage } \\
\text { of households) }\end{array}$ & Public hygiene condition recommended by WHO & $\begin{array}{l}\text { NSS 76th round } \\
\text { (2018) }\end{array}$ \\
\hline $\begin{array}{l}\text { Having an internet connection } \\
\text { (percentage of households) }\end{array}$ & $\begin{array}{l}\text { Media exposure providing information on COVID-19 pandemic } \\
\text { situation and connectivity }\end{array}$ & $\begin{array}{l}\text { NSS 75th round } \\
\quad(2017-18)\end{array}$ \\
\hline $\begin{array}{l}\text { Secondary level of education and } \\
\text { above (Proportion of population) }\end{array}$ & Positive development indicator, human capital, more awareness & $\begin{array}{l}\text { Census of India } \\
2011\end{array}$ \\
\hline $\begin{array}{l}\text { Hospital beds per hundred thousand } \\
\text { population }\end{array}$ & Availability of medical infrastructure & $\begin{array}{l}\text { Census of India } \\
\text { (2011) }\end{array}$ \\
\hline
\end{tabular}

cases); thus, the COVID cases at one location were affected by the COVID cases at the nearby locations. Mathematically, the spatial lag model is:

$\mathrm{Y}=\rho \mathrm{WY}+\mathrm{X} \beta+\varepsilon$

where, $\mathrm{Y}$ is an $\mathrm{N} \times 1$ vector of observations of the dependent variable, $\mathrm{WY}$ is an $\mathrm{N} \times 1$ vector of spatial lag for the dependent variables, and $\rho$ is the spatial autoregressive coefficient. $\mathrm{X} \beta$ is an $\mathrm{N} \times \mathrm{K}$ matrix of observation on the exogenous explanatory variables multiplied by a $K \times 1$ vector of regression coefficients $\beta$ for each $X$, and $\varepsilon$ is an $N \times 1$ vector of normally distributed random error terms. In the above equation, $\rho$ is a scalar parameter that indicates the effect of the dependent variable of the neighbouring regions on the dependent variable of a particular region.

\section{Results}

COVID-19 transmission in India

Since the reporting of the first COVID-19 case on 30 January in India, the disease spread substantially over the next few weeks (Fig. 1). Even after the preventive measure of nation-wide lockdown announced by the government against the transmission of the disease, the number of active cases increased with time. The first lockdown was announced from 24 March which extended to twenty-one days. The lockdown was extended to three more phases till June. With complete shutdown of almost all services the consequences were severe. Issues like joblessness, loss of income, food shortages affected the population. Manufacturing, mining, construction, trade, tourism etc. incurred economic loss. This impacted on the country's economic slowdown. On 30 May; lifting up of lockdown restrictions except for the containment zones were announced. From 1 June, the first Unlock phase initiated for thirty days. Unlock 2 was announced from 1 July and the third phase commenced from 1 August.

By the end of March, COVID-19 cases were sporadically concentrated in a few districts of Malappuram, Kasaragod of Kerala in the south, in and around Bengaluru (Karnataka), Mumbai (Maharashtra), Ahmedabad (Gujarat), New Delhi, a few districts of Punjab and Ladakh (Fig. 2). The transmission rapidly spread from people with recent travel histories from abroad and international tourists. Religious gatherings like events in Punjab and Delhi acted as virus spreaders among the population. According to the Health Ministry, a religious meeting in Delhi attributed to more than 4000 confirmed cases and at least 27 deaths across the country spreading as far as 
Fig. 1 COVID-19 pandemic lockdown in India (2020)

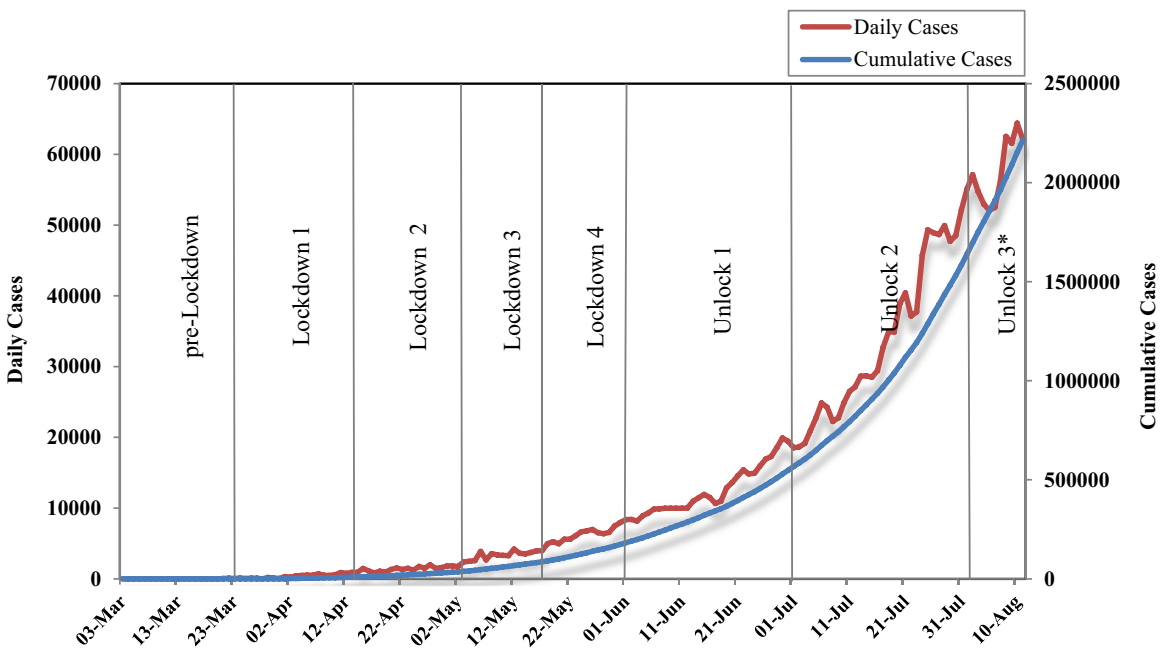

the Andaman and Nicobar Islands (PTI 2020; Dey 2020; Sharma 2020). An east-west divide of infections persisted in the country in April. Comparatively, lower cases were reported in eastern India, where urbanization was less than 20 percent in most districts (2011) except in the million-plus city of Kolkata and surroundings. The southern states of Kerala, Tamil $\mathrm{Nadu}$, and Karnataka had high number of cases by April's first week. By month-end, the numbers increased in districts of Maharashtra, Goa, Madhya Pradesh, Gujarat, and stretched to west Rajasthan, Delhi, Haryana, Punjab, and parts of Jammu and Kashmir including Ladakh. Hotspots of infections formed in Delhi, Mumbai, Bengaluru, Ahmedabad, Indore and Kolkata. The government extended the lockdown to 30 May. By 19 May, a diffusion of active cases occurred in rural districts of eastern India. Districts with huge out-migrating population of eastern Uttar Pradesh, western Bihar, West Bengal, Jharkhand, and Orissa witnessed a migrant induced rise in infections. The hotspots continued reporting active cases. With the first unlock from 1 June, there was a spike in infections across the country. Resumption of limited public transports, human movements transmitted the virus from highly infected areas to villages and towns. Over 21 hundred thousand infections were reported by 11 August except for a few districts in Arunachal Pradesh, Mizoram, and Himachal Pradesh (Fig. 2).

The uni-variate LISA score for 22 March of 0.10 indicated a low spatial autocorrelation of the disease among the districts (Fig. 3). Hotspot clustering was in
Delhi; Raigarh, Mumbai and Ahmednagar (Maharashtra); Rangareddy (Andhra Pradesh); Dakshin Kannada, Kasaragod, Kodagu, Kannur, Kozhikode and Alappuzha (Kerala) and Bangalore Rural (Karnataka). Though coldspots were absent yet a heterogeneous scatter of high-low designated districts existed. A month later, significant coldspots formed in the north-eastern and middle-eastern India. Hotspots of COVID-19 disappeared from the south, newer districts around Bhilwara (Rajasthan), Ahmedabad (Gujarat), and Indore (Madhya Pradesh) joined the list. Khorda in Odisha and Nagpur in Maharashtra had higher attribute values than their adjacent neighbours. Profound hotspots were observed in New Delhi, western Maharashtra around Mumbai, in eastern Tamil Nadu around Chennai and around Kolkata in West Bengal by 19 May. About 137 districts were in the low-low category. Over the next few months, the clustering of high-high districts became prolific in the above mentioned regions, and the numbers increased from fifteen on 3 June to twenty-five on 11 August. New Delhi had a decrease in the infected case numbers. The coldspots extended to 119 districts, mainly in Jammu and Kashmir, Uttarakhand, Himachal Pradesh, Madhya Pradesh, and vast parts of northeastern India.

\section{Urbanization and the spread of COVID-19}

Worldwide, the pattern of COVID-19 showed an initial concentration of infections in cities, and India was no exception. The proportion of confirmed cases 

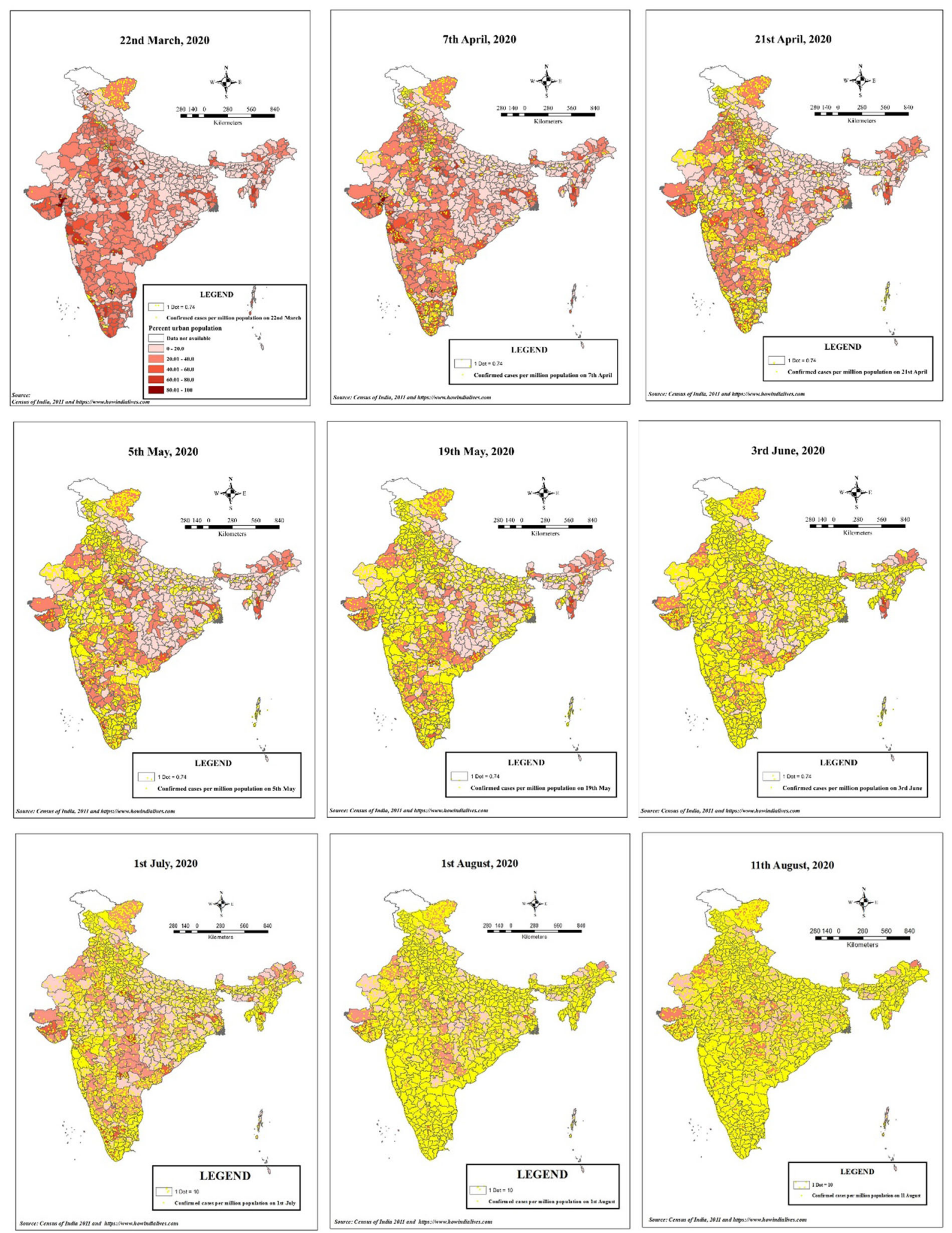

Fig. 2 Percent of urban population and confirmed Covid-19 cases day-wise district level India (March-August 2020) 

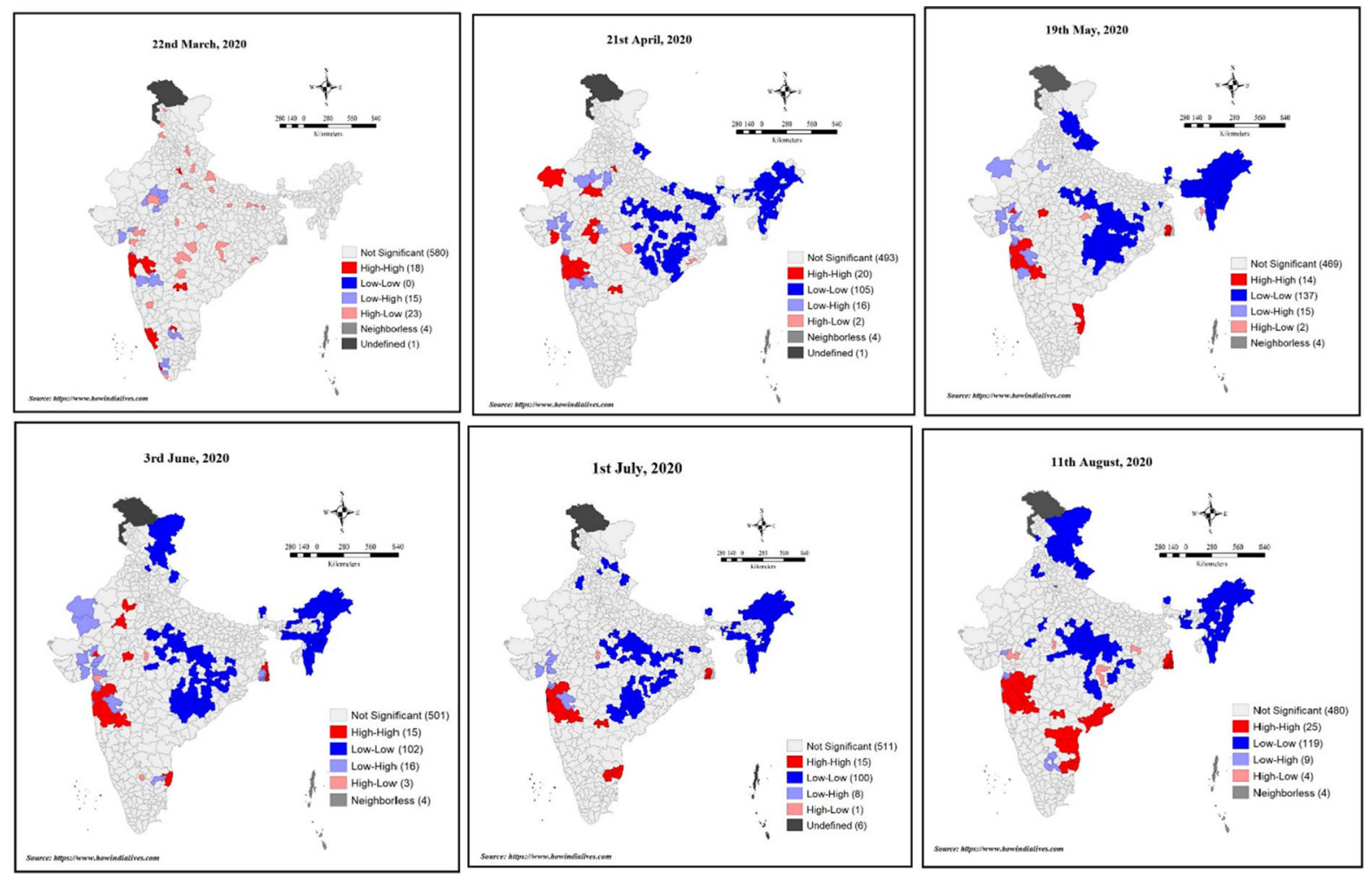

Fig. 3 Univariate LISA maps exploring COVID-19 clusters across districts of India for 22nd March, 21st April, 19th May, 3rd June, 1st July and 11th August 2020

in 53 million-plus cities and 121 urban majority districts (more than $40 \%$ urban population) of India were plotted from 22 March to 11 August 2020 (Fig. 4). On 22 March, among 401 registered cases, about 70 percent were reported from districts with more than 40 percent of urban population, whereas 60 percent was from the million-plus cities. On 5 May, more than three-fourths of the infected cases belonged to the 121 higher urban districts. The million-plus cities attributed over 72 percent cases. Jamshedpur was the only non-infected million-plus city. On 3 June, with relaxations in lockdown, India reported more than 207 thousand (MoHFW) cases, of which 67 percent were from million-plus cities. After almost two months, there was a considerable decrease in the share (44.7 percent); however, the total number of cases increased to more than 2.1 million.

On 22 March, about 42 percent of the highest urbanized districts reported COVID positive cases (Table 3). By 5 May about 90 percent of them reported cases. There was an upsurge of COVID-19 infections in the lockdown period. About 60 percent of the lower urbanized districts in the most urbanized states reported infections. Three-fourths of the lower urbanized districts and 115 higher urbanized districts reported cases on 19 May. With relaxations in human movements, there was a spike of infections. Unfavorable economic situation alongwith the fear of contraction of the disease created a wave of return migration of the informal workers. About 91 percent of lower urbanized districts confirmed infection, while 0.8 percent increase occurred in higher urbanized districts. The transmission diffused to 122 lower urbanized districts of states with a high urban population and 56 of 57 higher urbanized districts of the lower urbanized states within a fortnight. By 1 July, about 99 percent of the highest urbanized areas reported active cases, and less than ten districts reported no COVID-19 case. The situation remained similar except there was an increase in the total infections in the country.

Districts in India's highest urbanized states reported the maximum incidents since the beginning (Table 4). Mumbai, New Delhi, Hyderabad, and other million-plus cities primarily became the hotspots of 


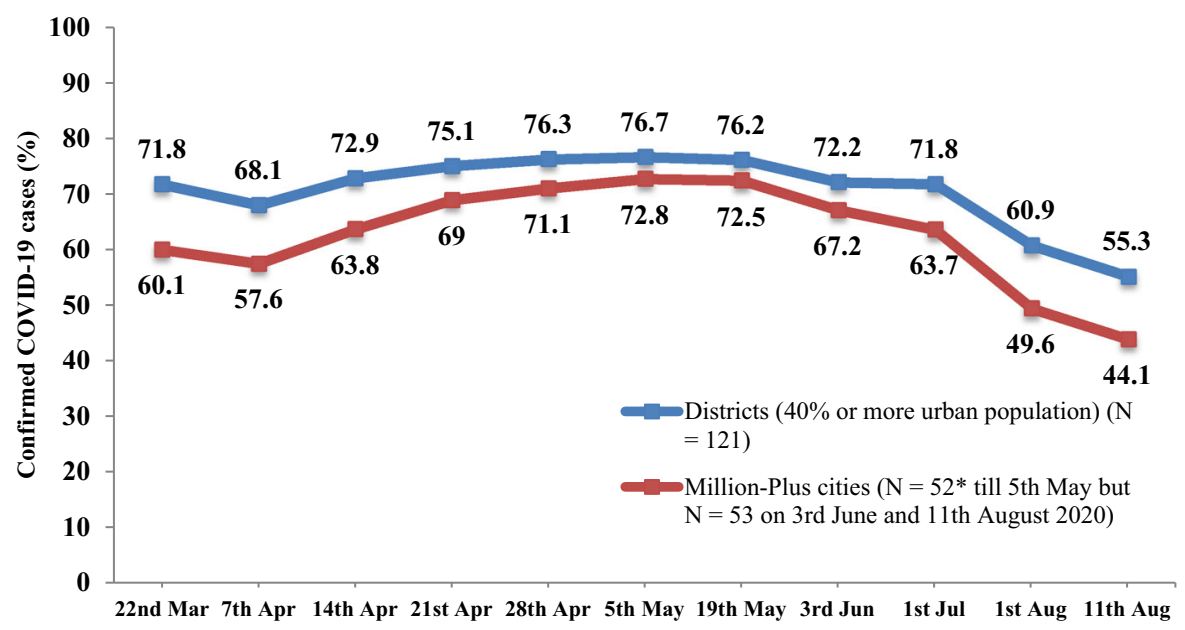

Fig. 4 Percentage of reported confirmed COVID-19 cases in urban areas India (March-June 2020)

Table 3 Districts reporting confirmed COVID-19 cases and percent of urban population. Source: Census of India, 2011 and https:// www.howindialives.com

\begin{tabular}{|c|c|c|c|c|c|c|c|c|}
\hline \multirow[t]{3}{*}{ Date } & \multicolumn{4}{|c|}{ States with $31 \%$ and more urban population $(\mathrm{n}=18)$} & \multicolumn{4}{|c|}{ States with less than $31 \%$ urban population $(n=17)$} \\
\hline & \multicolumn{2}{|c|}{$\begin{array}{l}\text { Higher urbanized districts } \\
(\mathrm{n}=125)\end{array}$} & \multicolumn{2}{|c|}{$\begin{array}{l}\text { Lower urbanized districts } \\
(\mathrm{n}=126)\end{array}$} & \multicolumn{2}{|c|}{$\begin{array}{l}\text { Higher urbanized districts } \\
(\mathrm{n}=57)\end{array}$} & \multicolumn{2}{|c|}{$\begin{array}{l}\text { Lower urbanized districts } \\
(\mathrm{n}=332)\end{array}$} \\
\hline & Abs nos & Percent & Abs nos & Percent & Abs nos & Percent & Abs nos & Percent \\
\hline $22-03-2020$ & 52 & 41.6 & 16 & 12.7 & 18 & 31.6 & 9 & 2.7 \\
\hline 07-04-2020 & 100 & 80 & 76 & 60.3 & 39 & 68.4 & 94 & 28.3 \\
\hline $21-04-2020$ & 110 & 88 & 94 & 74.6 & 45 & 78.9 & 145 & 43.7 \\
\hline $05-05-2020$ & 112 & 89.6 & 106 & 84.1 & 48 & 84.2 & 200 & 60.2 \\
\hline 19-05-2020 & 115 & 92 & 117 & 92.9 & 50 & 87.7 & 251 & 75.6 \\
\hline 03-06-2020 & 116 & 92.8 & 122 & 96.8 & 56 & 98.2 & 302 & 91 \\
\hline $01-07-2020$ & 124 & 99.2 & 125 & 99.2 & 57 & 100 & 325 & 97.9 \\
\hline 01-08-2020 & 124 & 99.2 & 125 & 99.2 & 57 & 100 & 330 & 99.4 \\
\hline $11-08-2020$ & 124 & 99.2 & 125 & 99.2 & 57 & 100 & 330 & 99.4 \\
\hline
\end{tabular}

the pandemic, confirming the urban-centric character of this virulent disease. The figures consistently rose in all of these areas and contributed 70 percent of the infected cases $(48,129$ cases) by 5 May. Higher urbanized districts from the lower urbanized states like Jaipur, Indore, and Ranchi reported 16 percent of the total by the same period. Contrary to this, lowest urbanized districts had less reporting. The number of cases crossed the first hundred thousand mark cumulatively in India by 19 May (MoHFW). With increasing human mobility, about 8.6 percent of the cases belonged to the lowest urbanized regions. Though the proportion is a meager to 71 percent as reported from the highly urbanized areas, yet it showed a 2 percent increase than earlier reporting from these regions. A grave situation was reflected in the less urbanized districts by 3 June where it increased to 12.8 percent, a 4.2 percent within a fortnight. Occurrences decreased by 2 percent in the higher urbanized districts for the same duration. By early July, about 71 percent of the cases were contributed from the higher urbanized regions of the higher urbanized states of India. However, this decreased by almost 10 percent while the contribution of the lower urbanized districts in 
Table 4 Distribution of confirmed COVID-19 cases in districts of India according to percentage of urban population. Source: Census of India, 2011 and https://www.howindialives.com

\begin{tabular}{|c|c|c|c|c|c|c|c|c|c|}
\hline \multirow[t]{3}{*}{ Date } & \multirow[t]{3}{*}{$\begin{array}{l}\text { Total no. of } \\
\text { confirmed cases }\end{array}$} & \multicolumn{4}{|c|}{$\begin{array}{l}\text { States with } 31 \% \text { and more urban population } \\
(\mathrm{n}=18)\end{array}$} & \multicolumn{4}{|c|}{$\begin{array}{l}\text { States with less than } 31 \% \text { urban population } \\
(\mathrm{n}=17)\end{array}$} \\
\hline & & \multicolumn{2}{|c|}{$\begin{array}{l}\text { Higher urbanized } \\
\text { districts }(\mathrm{n}=125)\end{array}$} & \multicolumn{2}{|c|}{$\begin{array}{l}\text { Lower urbanized } \\
\text { districts }(\mathrm{n}=126)\end{array}$} & \multicolumn{2}{|c|}{$\begin{array}{l}\text { Higher urbanized } \\
\text { districts }(\mathrm{n}=57)\end{array}$} & \multicolumn{2}{|c|}{$\begin{array}{l}\text { Lower urbanized } \\
\text { districts }(\mathrm{n}=332)\end{array}$} \\
\hline & & Abs nos & Percent & Abs nos & Percent & Abs nos & Percent & Abs nos & Percent \\
\hline $22-03-2020$ & 401 & 263 & 65.6 & 48 & 12 & 62 & 15.5 & 28 & 7 \\
\hline 07-04-2020 & 5271 & 3220 & 61.1 & 762 & 14.5 & 857 & 16.3 & 432 & 8.2 \\
\hline $21-04-2020$ & 19,803 & 12,655 & 63.9 & 1715 & 8.7 & 3821 & 19.3 & 1612 & 8.1 \\
\hline $05-05-2020$ & 48,129 & 33,115 & 68.8 & 4112 & 8.5 & 7638 & 15.9 & 3264 & 6.8 \\
\hline $19-05-2020$ & 99,182 & 70,456 & 71 & 7984 & 8.1 & 12,188 & 12.3 & 8554 & 8.6 \\
\hline 03-06-2020 & 188,947 & 130,188 & 68.9 & 15,541 & 8.2 & 19,013 & 10.1 & 24,205 & 12.8 \\
\hline 01-07-2020 & 502,081 & 354,618 & 70.6 & 47,707 & 9.5 & 40,477 & 8.1 & 59,279 & 11.8 \\
\hline 01-08-2020 & $1,579,644$ & 968,680 & 61.3 & 267,777 & 17.0 & 142,806 & 9.0 & 200,381 & 12.7 \\
\hline $11-08-2020$ & $2,194,849$ & $1,217,953$ & 55.5 & 419,808 & 19.1 & 215,661 & 9.8 & 341,427 & 15.6 \\
\hline
\end{tabular}

these states increased by 7 percent of the total. By 11 August 2020; a tremendous increase of 11 percent cases was reported from the lower urbanized districts while the reported cases from the highest urbanized districts decreased in the country's higher urbanized states.

\section{COVID-19 incidences and air travel}

The highly transmittable disease was brought into India by passengers returning from abroad. The initial cases had travel histories from Wuhan. The first fatality of the country was a man who had traveled from Saudi Arabia. Along with Indians returning from abroad, many cases came up among the international tourists (15 infected members of an Italian tourist group as reported on 4 March) (The Hindu 2020). Air travel in India was discontinued from $22 \mathrm{March}$. About 45 percent of the initial concentration of infections were in districts with busiest international and domestic airports (Table 5). Districts with only domestic airports reported 14 percent of the total cases. The adjoining districts sharing common administrative boundaries reported 29 percent of the affected cases. Human mobility significantly inflicted the spread of the disease. With an increase in distance between the districts and the airports, the reporting subsequently lessened. After a fortnight with restrictions in air travel, there was a decline in infection in districts with both international and domestic airports (38.9\%) and only domestic airports (10.8\%). Considering the incubation period of two weeks of showing the first symptoms of COVID-19, districts adjoining the airports $(32.6 \%)$ reported more cases compared to other districts (17.8\%). Infection was reported across new regions that initially had no cases by mid-April. During lockdown, air travel was restricted entirely except for some special arrangements made by the Indian government. However, the hotspots continued reporting a rise in the number of COVID patients daily. With the resumption in air travel, about 54 percent of the cases corresponded from districts having airports. Domestic air travel was relatively less till 3 June. Thus, this escalation in numbers was attributed to the air traffic and direct human-to-human contact by not adhering to the rules and precautions (The Hindu 2020). A high percentage (28.9\%) of cases was reported from airport adjoining districts.

\section{Human movements in COVID-19 hotspots}

The national lockdown announced on 22 March was officially the last operational airflow day in the country. Fifteen days later, about 5,271 COVID-19 cases were confirmed. Though the proportion of infection amongst more than 1.3 billion population was a tiny share, the disease was clustered in cities and districts with a higher urbanization rate than the 
Table 5 Distribution of confirmed COVID-19 cases in districts of India according to their proximity near airports (international and domestic). Source: https://www.howindialives.com and Airports Authority of India, 2020

\begin{tabular}{rlllll}
\hline Date & $\begin{array}{l}\text { Total no. of } \\
\text { COVID-19 } \\
\text { cases }\end{array}$ & $\begin{array}{l}\text { Percentage of cases in } \\
\text { districts with international } \\
\text { airports }\end{array}$ & $\begin{array}{l}\text { Percentage of cases in } \\
\text { districts with domestic } \\
\text { airports }\end{array}$ & $\begin{array}{l}\text { Percentage of cased in } \\
\text { adjoining districts of } \\
\text { airports }\end{array}$ & $\begin{array}{l}\text { Percentage of } \\
\text { cases in other } \\
\text { districts }\end{array}$ \\
\hline $\begin{array}{r}22-03- \\
2020\end{array}$ & 401 & 45.1 & 13.5 & 29.2 & 12.2 \\
$07-04-$ & 5271 & 38.9 & 10.8 & 32.6 & 17.8 \\
2020 & & & & & \\
\hline
\end{tabular}

national average. The top ten million-plus cities/ districts contributed about 39 percent of the total number of infected cases, with Mumbai solely contributing to 12 percent (Table 6). Except for Kasaragod, the other nine highest affected districts had airport terminals. In the Mumbai metropolitan region, both Mumbai and Thane districts were among the top ten infected areas similar to South Delhi and Southwest Delhi in the NCR. Comparison with the city-wise cumulative air traffic handled, two of the busiest airport cities of India were among the top ten COVID affected regions, i.e., Mumbai and Delhi. The Indira Gandhi International Airport in Delhi handled 28 percent of the total international and 18 percent of the domestic air passengers from January to March 2020. The Chhatrapati Shivaji International Airport handled about 19 percent of the international traffic along with a 12 percent share of the total domestic airflow for the same duration. These ten cities are well connected with a high road network as $52 \mathrm{~km}$. per hundred sq. $\mathrm{km}$. in Indore and $26 \mathrm{~km}$. per hundred sq. Km. in Chennai and railway connectivity as $21 \mathrm{~km}$. per hundred sq. Km. in Chennai and $19 \mathrm{~km}$. per hundred sq. $\mathrm{Km}$. in Indore. A significant proportion of the transmission attributed to regions with good connectivity. On 7 April, about 63 percent of the total cases originated from five states; Maharashtra (19.4\%), Andhra Pradesh (13.3\%), Tamil Nadu (12.9\%), Delhi $(10.7 \%)$ and Kerala (6.4\%). Cumulatively they handled about 79 percent of the international airflow and 53 percent of the domestic air travel.

Modes of transmission of COVID-19 in India

Humans were the primary vectors in transmitting COVID-19. By 22 March, most of the reported cases were due to travel reasons, more specifically international air travel (67.3\%). Family members of patients $(16.5 \%)$ were infected next (Table 7$)$. With restrictions in air travel, the transmission through international travel lessened $(16.9 \%)$ in the later phases. However, domestic travel still contributed to the maximum spread (52.9\%). Accidental exposure to infected individuals $(15.1 \%)$ chiefly due to lack of awareness increased transmission in the interval, 23 March and 8 April. It contributed to almost 65 percent of the total transmission between 8 April and 5 May. International air travel contributed to almost 12 percent and 22 percent in the higher and lowers urbanized districts by 5 May. Domestic travel contributed nearly 41 percent and 32 percent in these categories. Exposure to infected individuals in places of gathering attributed a high percentage in the spread of the epidemic ( $34.6 \%$ and $28.5 \%$, respectively). With the insurgence of outbreaks amongst a larger population, the transmission details became challenging to collect.

Effects of urbanization and transit mediums on the pandemic

The incidents of COVID-19 in India followed a clear spatial clustering of high and low COVID-19 cases at the district level. Thus, districts contiguous to each other had similar incidents of COVID-19 cases. At the beginning of the pandemic, million-plus cities and higher urbanised districts had a higher share of infections. Districts with airports reported higher incidence of cases up to April. In this section, we constructed three separate sets of OLS models and their spatial lag variants to understand the association between disease concentration urbanization and transit mediums. 


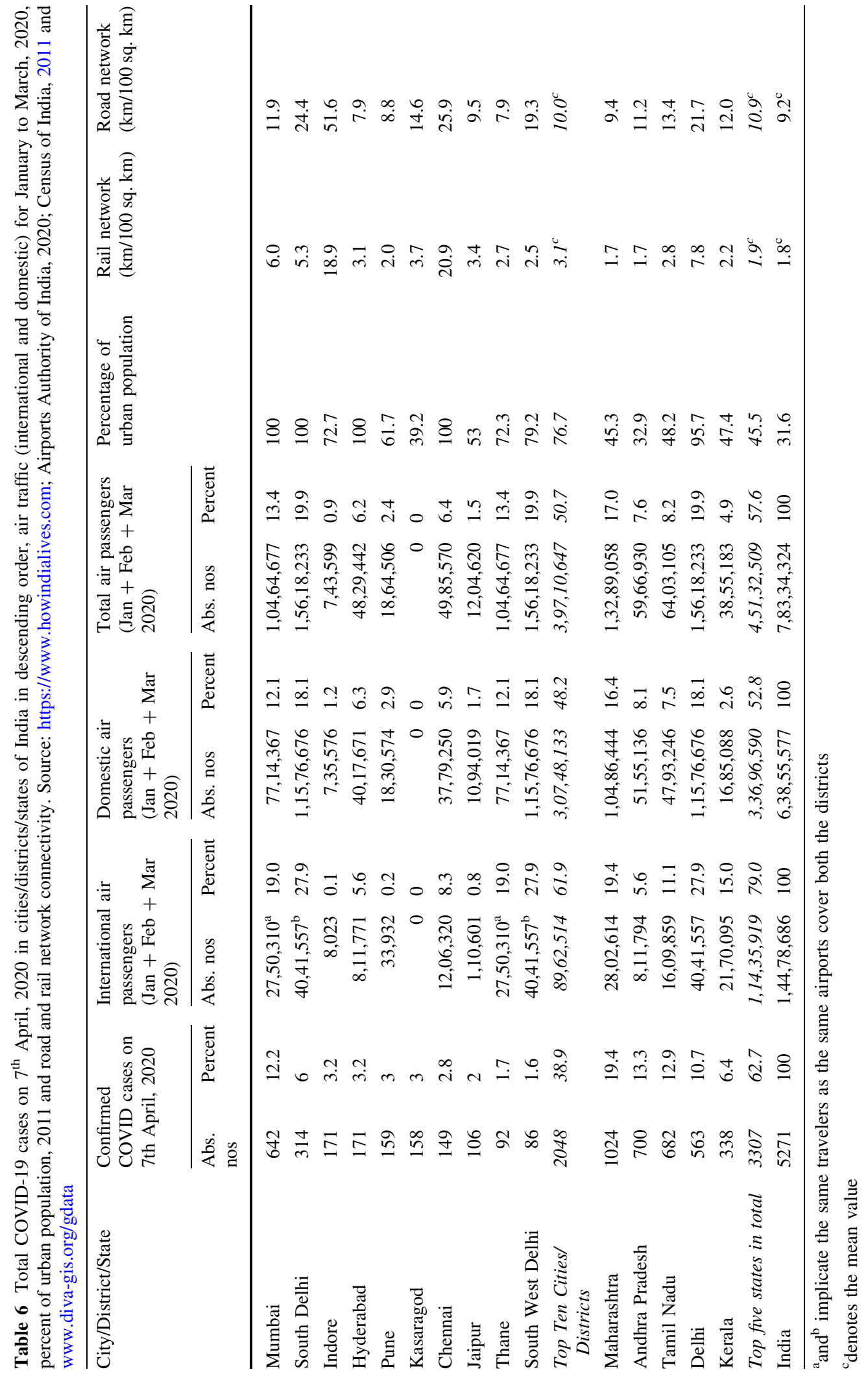




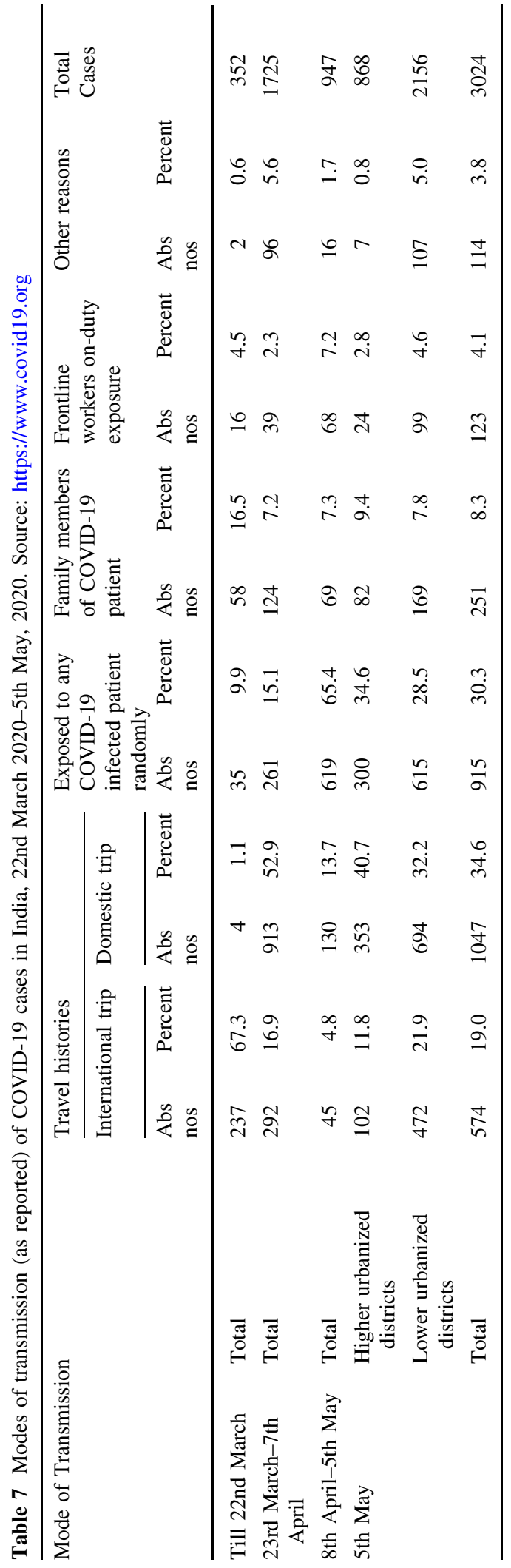

Table 8 showed significant and positive values of the spatial interaction term (Rho) across all of the spatial lag models which indicated the inherent spatial dependence in COVID-19 transmission, measuring the average influence on districts by their neighbouring districts. As a result, compared to their OLS variants, the overall model fit improved, as indicated in higher values of R-square and smaller values of Akaike info Criterion. When compared, the effect of other covariates between OLS models and their spatial lag variants the effects remained almost the same.

Model IB illustrated the effects of only urbanisation on the spread of the pandemic while controlling for the spatial effect. This model showed that urbanisation was significantly and positively associated with the number of infections. Rho was significantly positive, implying the crucial role of spatial contiguity in the spread of this disease. Model IIB examined the effects of transit mediums along with the spatial interaction term. Rho and the three transit mediums were in positive association with the spread of the pandemic. Model IIIB was the complete model where the effects of urbanisation and transit mediums were calculated after controlling all other relevant covariates and the spatial interaction term. Urbanisation was positively associated with COVID-19 cases at 1 per cent level of significance. Rail line density and presence of an airport in a district were positively associated with infected cases. Singh et al. (2020) listed about 4,150 Shramik trains operated and lowered the transportation crisis in post-lockdown period for 55 lakh labourers. Most of the trains departed from Gujarat, Maharashtra and Punjab and travelled to Uttar Pradesh, Bihar, Jharkhand, Odisha, Madhya Pradesh, Rajasthan and West Bengal (ibid). This return migration caused a surge in the COVID-19 cases in the rural districts as the first unlock period started from June.

Practice of hand-washing with soap was used as a proxy for better hygiene condition which showed a significant negative association to the spread of the pandemic. As recommended by WHO (2020), maintenance of good personal hygiene especially washing hands regularly protects against contagious infections. The Government of India extensively tried to create awareness during this crisis through printed, visual and audio media. Internet availability at the household level was used as a proxy of exposure to media which again showed a negative relationship with total infections and played a significant role in curbing the 
transmission. Spreading awareness and message briefs about maintaining good personal hygiene, abiding lockdown rules, maintaining adequate social distancing in public places, following government guidelines, Aarogya Setu application download was possible through internet connectivity. However, poor connectivity or lack of facilities at home (Ganguly et al. 2020) posed difficulty in remote areas. Higher educated population indicated a better human capital concentration and more hospital beds per hundred thousand people were positively associated with COVID-19 cases. These factors may be related to each other as people in urban areas often are higher educated and medical infrastructure remains better in cities than villages where more active cases were reported.

\section{Discussion}

Despite all the research on the predictive factors, health-seeking behavior, effects of lockdown, or estimating the outbreak's epidemiology, very few papers aimed to understand the underlying factors of diffusion of the pandemic. The global crisis featured a locational aspect which has even been asymmetric even within the countries at the local and regional level (Avetisyan 2020). The transmission showed a familiar pattern of emergence, initially urban-centric, and then to other parts in India. Million-plus cities contributed three-fourths of total cases from the beginning. Excellent connectivity, density, informal housing, etc. played significant roles in this transmission. Financial capital; Mumbai, the administrative capital of New Delhi, southern districts of Kerala, Tamil Nadu, Karnataka, and Andhra Pradesh became the hotspots. The travel routes of human movements especially airflow, directly impacted the infections in the cities. Refrained travelling to China and quarantining passengers with a travel history from China on 6 February (WHO 2020) was one of the initial measures by the government. Commutation to work being a regular urban phenomenon was a primary concern for

Table 8 Effects of urbanization and transit mediums on the spatial spread of COVID-19

\begin{tabular}{|c|c|c|c|c|c|c|}
\hline Variables & $\begin{array}{l}\text { Model IA } \\
\text { (OLS) } \\
\text { Coefficient }\end{array}$ & $\begin{array}{l}\text { Model IB } \\
\text { (Spatial Lag) } \\
\text { Coefficient }\end{array}$ & $\begin{array}{l}\text { Model IIA } \\
\text { (OLS) } \\
\text { Coefficient }\end{array}$ & $\begin{array}{l}\text { Model IIB } \\
\text { (Spatial Lag) } \\
\text { Coefficient }\end{array}$ & $\begin{array}{l}\text { Model IIIA } \\
\text { (OLS) } \\
\text { Coefficient }\end{array}$ & $\begin{array}{l}\text { Model IIIB } \\
\text { (Spatial Lag) } \\
\text { Coefficient }\end{array}$ \\
\hline Percent urban population & $5.12 * * *$ & $4.49 * * *$ & & & $3.73 * * *$ & $2.95 * * *$ \\
\hline Rail line per 100 sq. Km & & & $1051.71 * *$ & $1169.00 * * *$ & 236.35 & $594.53 *$ \\
\hline Road per 100 sq. Km & & & 388.97 & $390.80 *$ & -351.08 & -223.03 \\
\hline Airport & & & $165.30 * *$ & $156.99 * * *$ & $52.11 *$ & $65.94 * *$ \\
\hline $\begin{array}{l}\text { Hand-washing with soap (\% of } \\
\text { households) }\end{array}$ & & & & & $-1.02 * *$ & $-0.83 * *$ \\
\hline $\begin{array}{l}\text { Availability of Internet (\% of } \\
\text { households) }\end{array}$ & & & & & $-1.98 * * *$ & $-1.78 * * *$ \\
\hline $\begin{array}{l}\text { Secondary and above education } \\
(\%)\end{array}$ & & & & & $4.94 * * *$ & $3.50 * * *$ \\
\hline $\begin{array}{l}\text { Hospital beds per hundred } \\
\text { thousand population }\end{array}$ & & & & & $0.60 *$ & $0.64 * * *$ \\
\hline Rho & - & $0.39 * * *$ & - & $0.46 * * *$ & - & $0.39 * * *$ \\
\hline Constant & 13.20 & -24.53 & 23.03 & -9.74 & -18.62 & -48.61 \\
\hline Number of observations & 640 & 640 & 640 & 640 & 640 & 640 \\
\hline Number of variables & 1 & 1 & 3 & 3 & 8 & 8 \\
\hline $\mathrm{R}$ squared & 0.16 & 0.26 & 0.09 & 0.24 & 0.22 & 0.32 \\
\hline Adjusted R-squared & 0.16 & & 0.08 & & 0.21 & \\
\hline Log likelihood & -4417.31 & -4386.54 & -4445.21 & -4402.08 & -4392.90 & -4361.67 \\
\hline Akaike info criterion & 8838.62 & 8779.08 & 8898.43 & 8811.15 & 8803.90 & 8743.35 \\
\hline
\end{tabular}

***, ** and $* *$ denote significant at 1,5 and 10 percent level of significance respectively 
the virus's potency to spread to the entire population (Desai 2020). Our findings showed that over 60 percent of the total COVID-19 cases were reported from the million-plus cities increased to more than 72 percent on 19 May and later lowered to 45 percent on 11 August. The highly urbanized districts continued to amplify their numbers. The problem with cities is that they create ecosystems of their own, with higher temperatures and less seasonal changes than their surroundings (Shochat et al. 2006; Bradley and Altizer 2007). As a result, the extent of the zoonotic diseases is prolonged, and the transmission is extended (Lindahl and Grace 2015). Home isolation, social distancing, or testing everyone was challenging for highly populated slums like Dharavi in Mumbai, where about eight hundred thousand people live in 2.1 sq. Km. (Gupta 2020). A negative correlation existed between the regional variation of COVID cases and hygiene practices like washing hands with soap and having internet connections and roads per hundred sq. $\mathrm{Km}$. Lesser transport options led to a lower incidence of the spread of the infection, and post lockdown the burden of the cases in the urban hotspots lowered. With the regeneration of rail connectivity, there was an increase in transmission in rural districts. The shutdown of all employment sectors and no wages observed an exodus of informal workers from more prominent urban centres to their native places in the less urbanized areas. As a result, by 19 May, about 75 percent of the rural majority districts reported infections. Vignier and Bouchaud (2018), concluded in their study, that immigrants do not play a sentinel role in epidemics but they might play a crucial role in importing multidrug resistant emerging infectious diseases to places of destination. The concern remained for community transmission to villages and small towns that lacked health management infrastructure to face the alarming situation.

Regardless of the findings, our study had several limitations. First, the data quality might have significantly affected our inferences. We used published COVID-19 data from two sources, which had their own shortcomings, mainly because of lack of homogeneous reporting. The outcome of every infection was unavailable, especially in the later phase. Second, the lack of historical data of passengers' location by the road and rail route made it impossible to create the network of the monthly traffic network and predict transmission routes. Last, we did not consider other vital factors like the presence of co-morbidities, quality of care received, and other demographic factors like the age or sex distribution of the confirmed cases for the study.

\section{Conclusion}

The transmission of COVID-19 in India confirmed its initial urban-centric character. In the pre-lockdown and the post-lockdown stages, the functioning of the transport networks attributed significantly in transmitting the disease from the high urban containment zones. Later, there was a gradual shift of infections from urban to rural areas; however, cases kept increasing in the former. The massive reverse migration post-lockdown spiked the active cases. In India, where socio-economic issues like homelessness, daily wage payments, unemployment, and lack of social security pre-exist; the nation-wide lockdown's inadequate planning further deteriorated the condition. Disorganized connectivity created a complete chaos, and financial insecurity of the informal workers forced them to walk their way back, many losing lives to accidents, over-exhaustion and hunger. India's primary concern in the time of pandemic continued to be high population; ill-equipped public health system and insufficient resources to provide medical care to all.

Suggesting an action plan that can curb the pandemic is impossible from our elementary observations. Measurements to stop the spread at the original location was crucial. It was important to pass on and share knowledge about the disease to the global community (Neiderud 2015) at the initial stage. Introduction of policies to relax the lockdown in cities strategically and gradually (Telles 2020) with additional new physical distancing methods is essential. Strategies like the Bhilwara model (Rajasthan), the Kerala model, and the Dharavi model (Mumbai) against the transmission were efficient in different time intervals. Investments strengthening health infrastructure are essential. Rural-to-urban migration is inevitable; thus, improvement of living conditions through policy interventions is required.

The COVID-19 situation exposed different shortcomings in managing the effective functioning of cities during such health crisis. On the one hand, adverse human interventions on the environment might have led to the initial occurrence of the 
pandemic, yet the impact of socio-economic factors like job insecurity, overcrowding, houselessness played much more if not an equal role in its spread. Emphasis on mitigating the challenges in city planning remains unaddressed instead of encouraging unprecedented urban growth. Preparedness to restrict infectious diseases at the community levels is better than the task of finding a cure for life-threatening pandemics after their spread. Disease control and monitoring, needs to be a multi-disciplinary approach. It must include social and environmental values along with the science of medicine and epidemiology.

\begin{abstract}
Author contributions All authors contributed to the study conception, design and visualization. Material preparation, data collection and analysis were performed by Devarupa Gupta, Dibyendu Biswas and Pintu Kabiraj. The first draft was written by Devarupa Gupta and Dibyendu Biswas commented on this version of the manuscript. All authors read and approved the final manuscript.
\end{abstract}

Data availability This study is based on secondary data sources of Census of India (https://censusindia.gov.in/), 2011, NSS 75th \& 76th rounds (http://www.mospi.gov.in/) and two non-government data sources namely, https://www. howindialives.com and https://www.covid19india.org/ which are all available in the public domain for free of cost. No ethical clearance was required for the utilization of the datasets.

\section{Compliance with ethical standards}

Conflicts of interest The authors declare that there was no potential conflicts of interest while conducting the research or preparing the manuscript. No research grant was obtained from funding agencies to prepare this manuscript. This study has been carried out using secondary data and did not involve any human participants or animals. All the data are available in the public domain thus, no Informed consent was required.

\section{References}

Abdullah, A. S. M., Thomas, G. N., McGhee, S. M., \& Morisky, D. E. (2004). Impact of severe acute respiratory syndrome (SARS) on travel and population mobility: Implications for travel medicine practitioners. Journal of travel medicine, 11(2), 107-111.

Andrews, J. R., Morrow, C., Walensky, R. P., \& Wood, R. (2014). Integrating social contact and environmental data in evaluating tuberculosis transmission in a South African township. The journal of infectious diseases, 210(4), 597-603. https://doi.org/10.1093/infdis/jiu138

Anselin, L., Syabri, I., \& Kho, Y. (2006). GeoDa: An introduction to spatial data analysis. Geographical Analysis, $38(1), 5-22$.
Arora, P., Kumar, H., \& Panigrahi, B. K. (2020). Prediction and analysis of COVID-19 positive cases using deep learning models: A descriptive case study of India (p. 139). Solitons \& Fractals: Chaos.

Avetisyan, S. (2020). Coronavirus and urbanisation: do pandemics are anti-urban? Retrieved from https://papers.ssrn. com/sol3/papers.cfm?abstract_id=3584395.

Biswas, S. K., Ghosh, J. K., Sarkar, S., \& Ghosh, U. (2020). COVID-19 Pandemic in India: A mathematical model study. Nonlinear Dynamics, 102, 537-553. https://doi.org/ 10.1007/s11071-020-05958-z

Bradley, C. A., \& Altizer, S. (2007). Urbanization and the ecology of wildlife diseases. Trends in ecology \& evolution, 22(2), 95-102.

Cartwright, F.F., \& Biddiss, M.D. (1972). Disease and history. Crowell.

Census of India. (2011). Census of India 2011 Provisional Population Totals. New Delhi: Office of the Registrar General and Census Commissioner.

Curtin, P. D. (1989). Death by Migration: Europe's Encounter with the Tropical World in the 19th century. Cambridge: Cambridge University Press.

Desai, D. (2020). Urban Densities and the Covid-19 Pandemic: upending the sustainability myth of global megacities. Observer Research Foundation (ORF) Occasional Paper, 244(4).

Dey, S. (19 April 2020). $30 \%$ of cases across India tied to Jamaat event: Govt. The Times of India. Retrieved from https:// timesofindia.indiatimes.com/india/corona-cases-in-india30-of-cases-across-india-tied-to-jamaat-event/ articleshow/75227980.cms.

Ganguly, D., Misra, S., \& Goli, S. (2020). India's COVID-19 episode: resilience, response, impact and lessons. Retrieved from https://mpra.ub.uni-muenchen.de/99691/.

Gupta, S. (25 April 2020). Coronavirus: Mumbai's Dharavi, a COVID-19 hotspot, reports sharp drop in new cases, ndtv.com. Retrieved from https://www.ndtv.com/mumbainews/coronavirus-mumbaisdharavi-a-covid-19-hotspotreports-sharp-drop-in-new-cases-2217864.

Gushulak, B. D., \& MacPherson, D. W. (2000). Population mobility and infectious diseases: the diminishing impact of classical infectious diseases and new approaches for the 21st century. Clinical infectious diseases, 31(3), 776-780.

Hassell, J. M., Begon, M., Ward, M. J., \& Fèvre, E. M. (2017). Urbanization and disease emergence: dynamics at the wildlife-livestock-human interface. Trends in ecology \& evolution, 32(1), 55-67.

Hufnagel, L., Brockmann, D., \& Geisel, T. (2004). Forecast and control of epidemics in a globalized world. Proceedings of the national academy of sciences, 101(42), 15124-15129.

International Organization for Migration (IOM). (2003). World migration report: managing migration - challenges and responses for people on the move.

Jones, K. E., Patel, N. G., Levy, M. A., Storeygard, A., Balk, D., Gittleman, J. L., \& Daszak, P. (2008). Global trends in emerging infectious diseases. Nature, 451(7181), 990-993.

Katz, R., Mookherji, S., Kaminski, M., Haté, V., \& Fischer, J. E. (2012). Urban governance of disease. Administrative Sciences, 2(2), 135-147. 
Khajanchi, S., Sarkar, K., Mondal, J., \& Perc, M. (2020). Dynamics of the COVID-19 pandemic in India. Retrieved from https://arxiv.org/abs/2005.06286.

Khajanchi, S., \& Sarkar, K. (2020). Forecasting the daily and cumulative number of cases for the COVID-19 pandemic in India. Chaos: An interdisciplinary journal of nonlinear science. https://doi.org/10.1063/5.0016240

Khajanchi, S., Bera, S., \& Roy, T. K. (2020). Mathematical analysis of the global dynamics of a HTLV-I infection model, considering the role of cytotoxic T-lymphocytes. Mathematics and Computers in Simulation, 180, 354-378. https://www.sciencedirect.com/science/article/ abs/pii/S0378475420303177.

Kissler, S. M., Gog, J. R., Viboud, C., Charu, V., Bjørnstad, O. N., Simonsen, L., \& Grenfell, B. T. (2019). Geographic transmission hubs of the 2009 influenza pandemic in the United States. Epidemics., 26, 86-94.

Kucharski, A. J., Russell, T. W., Diamond, C., Liu, Y., Edmunds, J., Funk, S., Eggo, R. M., Sun, F., Jit, M., Munday, J. D., \& Davies, N. (2020). Early dynamics of transmission and control of COVID-19: a mathematical modelling study. The lancet infectious diseases., 20(5), 553-558. https://doi.org/10.1016/S1473-3099(20)30144-4

Lee, V. J., Ho, M., Kai, C. W., Aguilera, X., Heymann, D., \& Wilder-Smith, A. (2020). Epidemic preparedness in urban settings: new challenges and opportunities. The lancet infectious diseases, 20(5), 527-529.

Lessler, J., Salje, H., Grabowski, M. K., \& Cummings, D. A. (2016). Measuring spatial dependence for infectious disease epidemiology. PLOS ONE. https://doi.org/10.1371/ journal.pone.0155249

Lindahl, J. F., \& Grace, D. (2015). The consequences of human actions on risks for infectious diseases: a review. Infection Ecology \& Epidemiology. https://doi.org/10.3402/iee.v5. 30048

Mack, A., Choffnes, E. R., \& Relman, D. A. (Eds.). (2010). Infectious disease movement in a borderless world: workshop summary. United states: National Academies Press.

Mandal, S., Bhatnagar, T., Arinaminpathy, N., Agarwal, A., Chowdhury, A., Murhekar, M., Gangakhedkar, R. R., \& Sarkar, S. (2020). Prudent public health intervention strategies to control the coronavirus disease 2019 transmission in India: A mathematical model-based approach. The Indian journal of medical research, 151(2-3), 190-199. https://www.ncbi.nlm.nih. gov/pubmed/32202261.

Martens, P., \& Hall, L. (2000). Malaria on the move: human population movement and malaria transmission. Emerging infectious diseases, 6(2), 103-109. https://doi.org/10.3201/ eid0602.000202

McMichael, A. J., \& McMichael, T. (1993). Planetary overload: global environmental change and the health of the human species. Cambridge: Cambridge University Press.

Mitra, A., Pakhare, A. P., Roy, A., \& Joshi, A. (2020). Impact of COVID-19 epidemic curtailment strategies in selected Indian states: An analysis by reproduction number and doubling time with incidence modelling. PLOS ONE, 15(9), e0239026. https://doi.org/10.1371/journal.pone.0239026
Morens, D. M., Folkers, G. K., \& Fauci, A. S. (2008). Emerging infections: a perpetual challenge. The lancet infectious diseases, 8(11), 710-719.

Morens, D. M., Folkers, G. K., \& Fauci, A. S. (2004). The challenge of emerging and re-emerging infectious diseases. Nature, 430(6996), 242-249.

Myers, S. S., \& Patz, J. A. (2009). Emerging threats to human health from global environmental change. Annual review of environment and resources, 34, 223-252.

Nace, T. (22 March 2020). Population Adjusted Coronavirus Cases: Top 10 Countries Compared. Forbes. Retrieved from https://www.forbes.com/sites/trevornace/2020/03/ 22/population-adjusted-coronavirus-cases-top-10countries-compared/?sh=4313fb08974f.

Neiderud, C. J. (2015). How urbanization affects the epidemiology of emerging infectious diseases. Infection ecology \& epidemiology, 5(1), 1-9. https://doi.org/10.3402/iee.v5. 27060

O’Brien, E., \& Xagoraraki, I. (2019). Understanding temporal and spatial variations of viral disease in the US: The need for a one-health-based data collection and analysis approach. One Health, 8(September), 100105. https://doi. org/10.1016/j.onehlt.2019.100105

Patil, K., Murali, A., Ganguli, P., Nandi, S., \& Sarkar, R. R. (2020). Temporal Analysis of COVID-19 Pandemic in India and R0 prediction. Preprint (Version 1) available at Research Square.

Press Trust of India (PTI). (18 April 2020). Coronavirus: Nearly 4,300 cases were linked to Tablighi Jamaat event, says Health Ministry. The Hindu. Retrieved from https://www. thehindu.com/news/national/coronavirus-nearly-4300cases-were-linked-to-tablighi-jamaat-event-says-healthministry/article31376202.ece.

Rafiq, D., Suhail, S. A., \& Bazaz, M. A. (2020). Evaluation and prediction of COVID-19 in India: A case study of worst hit states. Chaos, Solitons \& Fractals, 139, 110014.

Rezza, G., Nicoletti, L., Angelini, R., Romi, R., Finarelli, A. C., Panning, M., Cordioli, P., Fortuna, C., Boros, S., Magurano, F., Silvi, G., Angelini, P., Dottori, M., Ciufolini, M. G., Majori, G. C., \& Cassone, A. (2007). Infection with chikungunya virus in Italy: an outbreak in a temperate region. The Lancet, 370(9602), 1840-1846.

Ryan, E. T., Wilson, M. E., \& Kain, K. C. (2002). Illness after international travel. The New England journal of medicine, 347(7), 505-516.

Saker, L., Lee, K., Cannito, B., Gilmore, A., \& CampbellLendrum, D. H. (2004). Globalization and infectious diseases: a review of the linkages (No. TDR/STR/SEB/ST/ 04.2). World Health Organization.

Samui, P., Mondal, J., \& Khajanchi, S. (2020). A mathematical model for COVID-19 transmission dynamics with a case study of India (p. 140). Solitons \& Fractals: Chaos.

Sarkar, K., Khajanchi, S., \& Nieto, J. J. (2020). Modeling and forecasting the COVID-19 pandemic in India (p. 139). Solitons \& Fractals: Chaos.

Sharma, N. C. (18 April 2020). 30\% covid-19 cases in India linked to Tablighi Jamaat event: Govt. Livemint. Retrieved from https://www.livemint.com/news/india/30-covid-19cases-in-india-linked-to-tablighi-jamaat-event-govt11587218560611.html. 
Shochat, E., Warren, P. S., Faeth, S. H., McIntyre, N. E., \& Hope, D. (2006). From patterns to emerging processes in mechanistic urban ecology. Trends in ecology \& evolution, 21(4), 186-191.

Singh, S. K., Patel, V., Chaudhary, A., \& Mishra, N. (2020). Reverse migration of labourers amidst COVID-19. Economic \& Political Weekly, 55(32-33), 25-29.

Telles, C. R. (2020). Influence of countries adopted social distancing policy for COVID-19 reduction under the view of the airborne transmission framework. JMIR Public Health and Surveillance. Accepted: 15 November 2020:20699 (in press). https://preprints.jmir.org/preprint/20699/accepted.

The Hindu Net Desk. (30 June 2020). Coronavirus India: Day 98 updates. The Hindu. Retrieved from https://www.thehindu. com/news/national/india-coronavirus-lockdown-june-302020-live-updates/article31950742.ece.

United Nations, Department of Economic and Social Affairs, Population Division (2019). The world's cities in 2018 Data Booklet.
Vignier, N., \& Bouchaud, O. (2018). Travel, migration and emerging infectious diseases. The Journal of the International Federation of Clinical Chemistry and Laboratory Medicine, 29(3), 175-179.

World Health Organization (WHO). (6 February 2020). Novel Coronavirus (2019-nCoV) Situation Report - 2. Retrieved from https://www.who.int/docs/default-source/wrindia/ india-situation-report-2.pdf?sfvrsn=962f294b_0.

Zhang, Y., Wang, X. L., Feng, T., \& Fang, C. Z. (2019). Analysis of spatial-temporal distribution and influencing factors of pulmonary tuberculosis in China, during 2008-2015. Epidemiology and Infection, 147, e25. https:// doi.org/10.1017/S0950268818002765

Publisher's Note Springer Nature remains neutral with regard to jurisdictional claims in published maps and institutional affiliations. 